Ida Katrine Riksaasen Hatlevik

Universitetet i Oslo

Kirsti Lyngvaer Engelien

Universitetet i Oslo

Doris Jorde

Universitetet i Oslo

DOI: http://dx.doi.org/10.5617/adno.7913

\title{
Universitetsskolers bidrag til utvikling av lærerutdanningen ved Universitetet i Oslo
}

\section{Sammendrag}

For å styrke kvaliteten på praksisopplæringen i lærerutdanningen og fremme FoUkompetansen i skolene, har Kunnskapsdepartementet (2017) løftet frem etablering av utvidede partnerskap mellom lærerutdanningsinstitusjoner, skoler/barnehager og skoleeiere, som et sentralt strategisk grep. Artikkelen bidrar med ny kunnskap om hvordan utvidede partnerskap kan fremme kvalitetsutvikling av mer enn bare studentenes praksisopplæring. Universitetet i Oslo har ti års erfaring med utvidet partnerskap i form av universitetsskolesamarbeid med utvalgte ungdoms- og videregående skoler. Samarbeidet tar utgangspunkt $i$ at universitet og skoler har ulike tilnærminger til læreres profesjonskunnskap. Begge tilnærmingene er essensielle, og til sammen gir de et godt utgangspunkt for å utforme og gjennomføre en god lærerutdanning. Artikkelen gir eksempler fra UiOs universitetsskolesamarbeid. Den analyserer disse i lys av indikatorer på velfungerende partnerskapssamarbeid mellom lærerutdanningsinstitusjon og praksisfelt, kvalitetsarbeid relatert til utvikling og vedlikehold av utdanningstilbud, og god lærerutdanning. Analysen av eksemplene viser for det første at i et velfungerende partnerskap kan universitetsskoler medvirke i kvalitetsarbeid i lærerutdanningen ved å være sentrale bidragsytere i forvaltning av lærerutdanningen, utvikling av studieprogram, emner, undervisnings-, vurderings- og praksisformer, og gjennomføring av undervisning på campus så vel som i praksis. For det andre viser eksemplene at tett samarbeid med universitetsskoler om studentenes læring på campus og i skolen kan gjøre utdanningens kunnskapsgrunnlag, undervisning og vurderingsformer mer profesjonsrelevante, og gi studentene gode rollemodeller for profesjonsutøvelse, også på campus. Videre bidrar artikkelen med et teoretisk rammeverk av kvalitetsindikatorer som kan brukes i utforming av nye utvidede partnerskap og til analyse av eksisterende.

Nøkkelord: utvidede partnerskap, universitetsskoler, kvalitetsarbeid, relevans, utdanningskvalitet 


\title{
The contribution of university schools to the development of Teacher Education at the University of Oslo
}

\begin{abstract}
Establishment of close and committed partnerships between teacher education institutions, a few selected teacher education schools (university schools), and school owners is an important strategy put forth by the Department of Education (2017) to strengthen the quality of practice in teacher education as well as to increase researchbased development in schools. In this article, we provide new knowledge of how partnerships with university schools are able to promote quality improvement in various parts of the teacher education program. The University of Oslo has ten years of experience working with university school relationships in which both types of institutions have unique and complementary ways of looking at and working with teacher professionalism in teacher education. The article provides examples from this partnership, analyzing them in light of indicators of: well-functioning partnerships between the teacher education institution and practice schools; quality work related to the development of study programs for teacher education; and good teacher education. The article's main findings are that in a well-functioning partnership, university schools are able to influence the quality of teacher education programs by contributing to the management of study programs, including courses, teaching, evaluation and practice forms on campus and within school practice. In addition, close connections between school and campus promote professional relevance for teacher education students and provide good role models for understanding the professionalism of becoming a teacher. The article also provides a theoretical framework of quality indicators that may be used in analyzing partnerships between teacher education intuitions and schools.
\end{abstract}

Keywords: close and committed partnerships, teacher education schools, quality work, relevance, educational quality

\section{Innledning}

I «Lærerutdanning 2025: Nasjonal strategi for kvalitet og samarbeid i lærerutdanningene» (Kunnskapsdepartementet, 2017) er nye, utvidede partnerskapsmodeller mellom institusjoner som tilbyr lærerutdanning, skoler/barnehager og skoleeiere løftet frem som et strategisk grep for å styrke kvaliteten i norsk lærerutdanning. Et sentralt mål i strategien er å legge til rette for langvarig og gjensidig samarbeid. Dette kan blant annet styrke kvaliteten i praksisopplæringen og bidra til at skolene lykkes med å etablere fagmiljøer med kvalifiserte praksislærere som samarbeider tett med fagmiljøene ved lærerutdanningsinstitusjonene. Vi argumenterer i denne artikkelen for hvordan slike utvidede partnerskap også kan være viktige for kvalitetsutvikling av den delen av utdanningsprogrammet som tilbys på campus.

Institutt for lærerutdanning og skoleforskning (ILS) ved Universitetet i Oslo (UiO) har ti års erfaring med utvidet partnerskap i form av universitetsskolesamarbeid, og var den første lærerutdanningsinstitusjonen i Norge som startet 
med å utvikle et slikt samarbeid ${ }^{1}$. I denne artikkelen bruker vi eksempler fra dette samarbeidet til å belyse følgende problemstilling:

\section{Hvordan kan utvidede partnerskap mellom larerutdanningsinstitusjon og skoler bidra til kvalitetsutvikling av laererutdanningen?}

I artikkelens teoridel redegjør vi for tidligere forskning som belyser kjennetegn på velfungerende partnerskap, kvalitetsarbeid i utvikling og vedlikehold av utdanningstilbud og god lærerutdanning. På bakgrunn av disse kjennetegnene har vi utviklet indikatorer for de nevnte forholdene som presenteres i tabell 1 . Indikatorene bruker vi til å analysere fem eksempler fra universitetsskolesamarbeidet ved UiO. Disse viser innhold i samarbeidet med særlig vekt på universitetsskolenes deltagelse i kvalitetsarbeid i lærerutdanningen. I metodedelen redegjør vi for datagrunnlag for beskrivelse av eksemplene fra universitetsskolesamarbeidet. I tillegg gir vi, som et bakteppe til å forstå eksemplene, en kontekstbeskrivelse av lærerutdanningen ved UiO med særlig vekt på Lektorprogrammet, og en kort oversikt over utviklingen av samarbeidet med universitetsskoler. Avslutningsvis oppsummerer vi universitetsskolenes deltagelse i kvalitetsarbeid i lærerutdanningen ved UiO og peker på hvordan tilsvarende utvidede partnerskap kan medvirke til økt kvalitet i lærerutdanningen ved å være sentrale bidragsytere i kvalitetsarbeid knyttet til utvikling, gjennomføring og forvaltning av lærerutdanningen, både på campus og i praksis. Vi peker også på behov for videre studier og utfordringer for videre samarbeid i godt etablerte utvidede partnerskap.

\section{Teoretisk rammeverk}

Kvalitet i utdanning brukes og forstås på ulike måter (se for eksempel Aamodt, Hovdhaugen \& Prøitz, 2014; Elken \& Stensaker, 2018; Gibbs, 2010; Handal, 1990; Hatlevik, 2016; Norgesnettrådet, 1999; Stensaker, 2013; Vestøl, 2015; Wittek \& Kvernbekk, 2011). Selve begrepet kvalitet kan kritiseres for å være innholdsløst. Kvalitet må alltid knyttes til noe konkret, som for eksempel en beskrivelse av vesentlige egenskaper ved objekter, produkter, prosesser, institusjoner eller utdanningsprogrammer (Wittek \& Kvernbekk, 2011). I vårt tilfelle $\emptyset$ nsker vi å belyse kvalitet i lærerutdanningen ved å se på hvordan utvidede partnerskap mellom lærerutdanningsinstitusjon og skole kan bidra til kvalitetsutvikling av hele lærerutdanningen. Forskning på partnerskap i lærerutdanningen (Lillejord \& Børte, 2014, 2016), kvalitetsarbeid (quality work) (Elken \&

\footnotetext{
${ }^{1}$ Ved tildelingen av Senter for fremragende utdanning i 2011, har dette forsknings- og utviklingsarbeidet skjedd gjennom The Centre for Professional Learning in Teacher Education, ProTed, som er et konsortiumssamarbeid mellom Universitetet i Oslo og Universitetet i Tromsø - Norges arktiske universitet. ProTed har siden oppstarten i 2012 samarbeidet med utvalgte universitetsskoler, og erfaringer fra disse modellene for utvidede partnerskap ved UiO og UiT ble også løftet frem i arbeidet med å utvikle Lærerutdanning 2025.
} 
Stensaker, 2018) og kvalitet i profesjonsutdanninger (Grossman et al., 2009a; Grossman, Hammerness \& McDonald, 2009b; Hatlevik, 2016; Sullivan, 2005; Vestøl, 2015) vurderes som særlig egnet til å belyse vårt anliggende. Nedenfor redegjør vi for hva denne forskningen bidrar med av kunnskap om forutsetninger for velfungerende partnerskap mellom lærerutdanning og skole, kjennetegn på kvalitetsarbeid i utvikling og vedlikehold av utdanningstilbud og kjennetegn ved en god lærerutdanning. På bakgrunn av dette gir vi i tabell 1 en punktvis sammenfatning i form av indikatorer på de nevnte forhold.

\section{Velfungerende partnerskap mellom lærerutdanningsinstitusjon og praksisfeltet}

Kunnskapssenter for utdanning utarbeidet i 2014 på oppdrag av ProTed en forskningskartlegging for å løfte frem forskning som bidrar til å belyse både forutsetninger for at utvidede partnerskap mellom lærerutdanning og praksisfeltet skal lykkes og hva slike utvidede partnerskapsmodeller potensielt kan ha av positiv betydning for både lærerutdanningsinstitusjonen og skolene (Lillejord \& Børte, 2014, 2016). «Studies included describe partnerships as complex and resource-intensive cross-institutional infrastructures for knowledge sharing, with the ambition to enhance the practice-relevance of teacher education, bridge theory and practice and support mentoring and professional learning» (Lillejord \& Børte, 2016, s. 550).

Lillejord og Børte $(2014,2016)$ fremhever at utvidede partnerskap mellom lærerutdanning og skoler kan bidra til kvalitetsutvikling av lærerutdanningen ved å gjøre utdanningen profesjonsrelevant. Samtidig er det kjent at slike samarbeidsrelasjoner innebærer utfordringer og spenninger (Breault \& Breault, 2010), og Lillejord og Børte (2014) peker på en rekke forutsetninger for at utvidede partnerskap i lærerutdanningen skal fungere etter hensikten. For det første er det viktig at partnerskapet vektlegger symmetri i betydningen at universitet og skole er likeverdige bidragsytere i lærerutdanningen. Likeverdighet handler om at begge parter anerkjenner at aktørene på begge læringsarenaene bidrar med viktig og komplementær kunnskap i lærerutdanningen. Likeverdige partnerskap omtales som et paradigmeskifte eller en rekonfigurering av forholdet mellom universitetene og skolesektoren (Zeichner, 2010; Ellis \& McNicholl, 2015). En annen forutsetning er å tilrettelegge for dialog mellom partene om hvordan samarbeidet skal utformes og gjennomføres. Dette innebærer både at det etableres møteplasser for samarbeid og at de ulike partene oppsøker og bidrar på hverandres arenaer.

En tredje forutsetning er anerkjennelse av at samarbeidet innebærer utveksling av tjenester, og at begge parter må oppleve at de har utbytte av samarbeidet ved at det gagner deres primære samfunnsoppdrag. For lærerutdanningsinstitusjonen innebærer dette at universitetsskolesamarbeidet bidrar til å utvikle kvaliteten på lærerutdanningen og dermed fremmer studentenes læring. Tilsvarende innebærer dette at universitetsskolene opplever at samarbeidet gagner skolens og de enkelte 
lærernes kompetanseutvikling og derigjennom elevenes læring. En fjerde forutsetning er at en har gjensidige og realistiske forventninger. En femte forutsetning er at en har noe konkret å samarbeide om, og en sjette at samarbeidet ikke er statisk, men i stadig utvikling. I tabell $1 \mathrm{er}$ de her nevnte forutsetningene formulert som indikatorer for velfungerende partnerskap (punktene 1.1-1.6). Nedenfor går vi nærmere inn på kjennetegn på kvalitetsarbeid knyttet til å utvikle og vedlikeholde en god lærerutdanning.

\section{Kvalitetsarbeid i utvikling og vedlikehold av utdanningstilbud}

Elken og Stensaker (2018) lanserte begrepet kvalitetsarbeid (quality work) som komplementært til begrepene kvalitetsstyring (quality management) og kvalitetskultur (quality culture), og som særlig egnet til å analysere prosesser knyttet til utvikling/styrking (enhancement) og vedlikehold (maintenance) av kvaliteten på utdanningstilbud i høyere utdanning. Elken og Stensaker (2018) påpeker at det ved utdanningsinstitusjoner foregår en rekke aktiviteter og praksiser som adresserer arbeid med å fremme og videreføre utdanningskvalitet, men som ikke fanges opp av analyser som fokuserer på kvalitetsstyring eller kvalitetskultur. De kaller dette kvalitetsarbeid. Kvalitetsarbeid innebærer en pragmatisk og dynamisk forståelse av kvalitet som et resultat av koordinering og kommunikasjon mellom ulike aktører som er involvert i utdanningen. Kvalitetsarbeid kan strekke seg over flere organisasjonsmessige nivåer og arenaer ved institusjonen, og innebærer både formelle og uformelle prosesser. Kvalitetsarbeid tar således ikke for gitt et spesifikt forutsigbart utbytte. Det tar i stedet utgangspunkt i behovet for å reforhandle $\mathrm{og}$ balansere ulike synspunkt, og det forutsetter en åpen prosess hvor intensjonen kan handle om å finne gode løsninger på konkrete problemer, innovasjon eller vedlikehold av utdanningsprogram. Sentralt i kvalitetsarbeid er derfor rollen til de enkelte aktørene og deres handlinger som grunnlag for å forstå både utvikling og vedlikehold av utdanningstilbud. På bakgrunn av denne beskrivelsen av kvalitetsarbeid har vi formulert fem indikatorer for kvalitetsarbeid i utvikling og vedlikehold av lærerutdanningens utdanningstilbud som er presentert i tabell 1 (punktene 2.1-2.5).

Ved å vektlegge kvalitetsarbeid som en viktig dimensjon ved utdanningskvalitet, får en frem betydningen av å studere prosesser som fremmer og viderefører kvalitet i lærerutdanningen. Elken og Stensaker (2018) argumenterer for at det er et stort behov for å analysere institusjoners kvalitetsarbeid for bedre å kunne forstå hva som kjennetegner slikt arbeid og hvordan det kan bidra til å sikre og utvikle kvalitet i utdanningen. Målet for samarbeidet med universitetsskoler om kvalitetsarbeid er å skape en god lærerutdanning. I begrepet kvalitetsarbeid ligger det imidlertid ingen beskrivelse av hva som kjennetegner en slik lærerutdanning. Vi ønsker derfor å komplettere indikatorene på et velfungerende partnerskapssamarbeid og kvalitetsarbeid med indikatorer på en god lærerutdanning. 


\section{God lærerutdanning}

I lærerutdanningen er det en intensjon at undervisningen på campus og praksis i skolene sammen skal fremme utvikling av adekvat profesjonskompetanse hos studentene (Smeby, 2008). Undervisningen på campus og praksisopplæringen i skolene står for ulike tilnærminger til profesjonskunnskapen. De er begge essensielle, og sammen bidrar de til å kvalifisere lærerstudentene til profesjonell praksis i skolene (Sullivan, 2005). Sullivan (2005) deler den kompetansen lærerstudentene skal utvikle inn i tre ulike kompetanse-/kunnskapsområder (three clusters of value): «the values of the academy, the values of professional practice, and the ethical-social values of professional identity» (s. 28). Disse tre kompetanseområdene tilsvarer i hovedsak det som på norsk betegnes som kunnskaper, ferdigheter og holdninger (Havnes, 2011, s. 35). Hvert av disse områdene utvikles i ulike læringskontekster - som betegnes som kunnskaps- og læringsfellesskap:

- Læringsfellesskapet for intellektuell eller kognitiv kunnskap, hvor fokus er på å lære analytisk refleksjon og bli kjent med forskning som utgjør fagfeltets vitenskapelige kunnskapsbase. Dette foregår typisk på campus.

- Læringsfellesskapet for praktiske ferdigheter, der studentene lærer ferdighetene til profesjonsutøverne gjennom å delta i praksissituasjoner som enten er simuleringer eller reell profesjonsutøvelse. Dette foregår typisk i skolene.

- Læringsfellesskapet for verdier og holdninger, der studentene blir kjent og fortrolig med profesjonens verdigrunnlag gjennom å lære om dem og praktisere dem. Et sentralt begrep her er utvikling av profesjonsidentitet. Dette læringsfellesskapet foregår hovedsakelig i skolene, men også på campus, og kan sees som overgripende for alt undervisnings- og opplæringstilbud som gis i utdanningen. Det kan derfor ikke begrenses til en egen undervisningskomponent/emne.

Kjennetegn på kvalitet i det første læringsfellesskapet har mange felles trekk med hva tidligere forskning (Chickering \& Gamson, 1987; Pascarella \& Terenzini, 2005; Pintrich, 2003; Ramsden, 2003) har fremhevet som generelle kjennetegn på god undervisning i høyere utdanning (for en detaljert gjennomgang se Hatlevik, 2016, 2018). Sammenfattet innebærer dette at god undervisning forutsetter at det kommuniseres tydelige mål for hva som skal læres, hvor godt det skal læres og begrunnelser for hvorfor det skal læres. Undervisningen bør vektlegge studentenes forståelse av innholdet og fokusere på nøkkelbegreper og sentrale deler av pensum. Den bør legge til rette for studentaktive læringsformer og samarbeid mellom studenter, og et trygt læringsmiljø slik at studenter tør være aktive. Videre kjennetegnes god undervisning av at underviserne selv er engasjert i det faglige innholdet de underviser i, varierer undervisningsformer, tilpasser undervisning etter studentenes forutsetninger og gir gode tilbakemeldinger på studentenes arbeid (punkt $3.1 \mathrm{i}$ tabell 1). 
Når det gjelder kunnskapsinnholdet i det første læringsfellesskapet, altså fagfeltets vitenskapelige kunnskapsbase, er det en ytterligere kompliserende faktor at profesjoners vitenskapelige kunnskapsbaser er hentet fra ulike fagdisipliner, og ikke nødvendigvis henger godt sammen rent teoretisk (Grimen, 2008). De ulike teoretiske og praktiske kunnskapskomponentene i profesjonsutdanninger er valgt ut fordi de på ulike måter kan brukes som grunnlag for senere profesjonsutøvelse (ibid.). For lærerutdanningen er det derfor i profesjonsut $\varnothing$ velsen i skolene en kan se hvordan ulike typer kunnskap og ferdigheter spiller sammen som nødvendig grunnlag for å planlegge, begrunne, gjennomføre og reflektere over praksis. Dette innebærer at praksisrelevant(e) kunnskapsinnhold, læringsaktiviteter og vurderingsformer er sentrale kjennetegn ved kvalitet i lærerutdanningen (punkt 3.2 i tabell 1). Vestøl (2015) omtaler «utdanningens relevans for studenter, elever, elevenes foreldre og skoleeiere» (s. 203) som et brukerperspektiv på kvalitet, og som av særlig interesse for lærerutdanningen. Et brukerperspektiv på kvalitet i lærerutdanningen er overgripende for de tre læringsfellesskapene (Sullivan, 2005) som er omtalt ovenfor. Når det gjelder undervisningen av teoretisk kunnskap på campus, fremhever Kvernbekk (2001) at om en teori er relevant for praksisut $\varnothing v e l s e n$ eller ikke, ligger ikke i teorien som en iboende egenskap. Relevans er noe man skaper ved å bruke og forklare hvordan teorier kan brukes, som grunnlag for og refleksjon over profesjonsutøvelse. Imidlertid viser tidligere forskning at lærerstudenter kan synes det er vanskelig å se relevans av og sammenheng mellom det de lærer på campus og det de lærer ved skolene i praksisperiodene (Grossman, Hammerness, McDonald \& Ronfeldt, 2008; Hatlevik \& Smeby, 2015; Jenset, Hammerness \& Klette, 2019; Smeby \& Heggen, 2014). Å gjøre kunnskapsinnholdets relevans tydelig for studentene kan derfor sees som en sentral utfordring for lærerutdanningen. For lærerutdanningsinstitusjonen viser dette at god kjennskap til og samarbeid med praksisarenaen er et viktig anliggende for alle aktører som bidrar til utforming av lærerutdanningsprogrammet og til gjennomføring av undervisning ved lærerutdanningen, både i profesjonsfaget og i fagstudiene (punktene 3.6 og $3.8 \mathrm{i}$ tabell 1 ).

$\mathrm{Vi}$ vil dessuten argumentere for at enkelte kjennetegn på kvalitet i det som Sullivan (2005) betegner som læringsfellesskapet for praktiske ferdigheter, og som tradisjonelt kan sies å beskrive kvalitet i praksisopplæringen, er av betydning også for den delen av lærerutdanningen som foregår på campus. Tidligere forskning viser at god praksisopplæring kjennetegnes av å gi studentene mulighet til å observere gode rollemodeller på yrkesutøvelse (Grossman et al., 2009b) (punkt 3.3 i tabell 1), og anledning til å prøve ut læringsaktiviteter som er sentrale for den faktiske profesjonsutøvelsen i klasserommet, såkalte kjernepraksiser (Darling-Hammond \& Bransford, 2005; Kennedy, 2016) (punkt 3.4 i tabell 1). I tillegg bør arbeidsoppgaver dekomponeres i enkeltferdigheter og det bør være en progresjon i praksisopplæringens kompleksitet (Grossman et al., 2009a; Grossman et al., 2009b; Billett \& Choy, 2013) (punkt 3.5 i tabell 1). Dette innebærer at studenter får $\emptyset$ ve på og prøve ut enkeltferdigheter, og da gjerne på 
campus før de skal gjennomføre mer komplekse arbeidsoppgaver i autentiske settinger i skolen. Zeichner (2002) peker på at veiledernes veiledningskompetanse og evne til å skape en trygg læresituasjon er avgjørende for en god opplevelse av praksisperioden. I selve veiledningen har studentene behov for gode tilbakemeldinger på egne fors $\emptyset \mathrm{k}$ på profesjonsutøvelse og at det settes av nok tid sammen med veileder til å reflektere og lære av både heldige og mindre heldige utfall av studentenes fors $\varnothing \mathrm{k}$ på profesjonsutøvelse (Beck \& Kosnik, 2002; Glenn, 2006). Det er også viktig at studentene får anledning til å reflektere over og relatere praktiske erfaringer og handlingsvalg til relevant teoretisk og forskningsbasert kunnskap (Beck \& Kosnik, 2002; Billett \& Choy, 2013; Glenn, 2006; Zeichner, 2002) (punkt 3.7 i tabell 1).

Hva studentene får ut av sin praksisopplæring, handler også om hvilke forkunnskaper de har og hvor godt forberedt de er på hva de kan forvente seg av praksis og hvordan de engasjerer seg i det opplæringstilbudet som gis (Billett \& Choy, 2013; Sullivan, 2005). For å øke kvaliteten på studentenes læring på arbeidsplassen er det derfor viktig å støtte studentenes læring i forkant, underveis og i etterkant av praksisperiodene (Billett \& Choy, 2013). Av denne gjennomgangen går det frem at studenters utbytte og opplevelse av en god praksisopplæring ikke bare handler om det som skjer i praksisperiodene, men også om det som skjer i undervisningen på campus i for- og etterkant. Gjennomgangen viser at tydeliggjøring av hvordan teoretisk og forskningsbasert kunnskap relaterer seg til praksisutøvelse, er et sentralt anliggende både for undervisningstilbudet som gis på campus og i praksisopplæringen i skolene. Dette igjen underbygger behovet for et nært samarbeid med praksisfeltet når det gjelder kvalitetsarbeid knyttet til utvikling og gjennomføring av lærerutdanningen (punkt 3.8 i tabell 1).

I tabell 1 gir vi på bakgrunn av den forskningen vi har presentert i det foregående, en punktvis sammenfatning i form av indikatorer på velfungerende partnerskapssamarbeid mellom lærerutdanningsinstitusjonen og praksisfeltet, kvalitetsarbeid relatert til utvikling og vedlikehold av lærerutdanningens utdanningstilbud, og god lærerutdanning. Denne listen kan fungere som en generell sjekkliste $\mathrm{i}$ forkant av utforming og $\mathrm{i}$ etterkant til evaluering og videreutvikling av utvidet partnerskapssamarbeid mellom lærerutdanningsinstitusjon, universitets-/lærerutdanningsskoler og skoleeiere i tråd med intensjonen i strategidokumentet «Lærerutdanning 2025» (Kunnskapsdepartementet, 2017). I denne artikkelen bruker vi tabell 1 som et rammeverk til å analysere eksempler fra universitetsskolesamarbeidet ved UiO, hvor vi søker å løfte frem hvordan universitetsskolene kan bidra i arbeid med kvalitetsutvikling av lærerutdanningen. 
Tabell 1. Indikatorer på velfungerende partnerskapssamarbeid mellom lærerutdanningsinstitusjonen og praksisfeltet, kvalitetsarbeid i utvikling og vedlikehold av lærerutdanningens utdanningstilbud og god lærerutdanning.

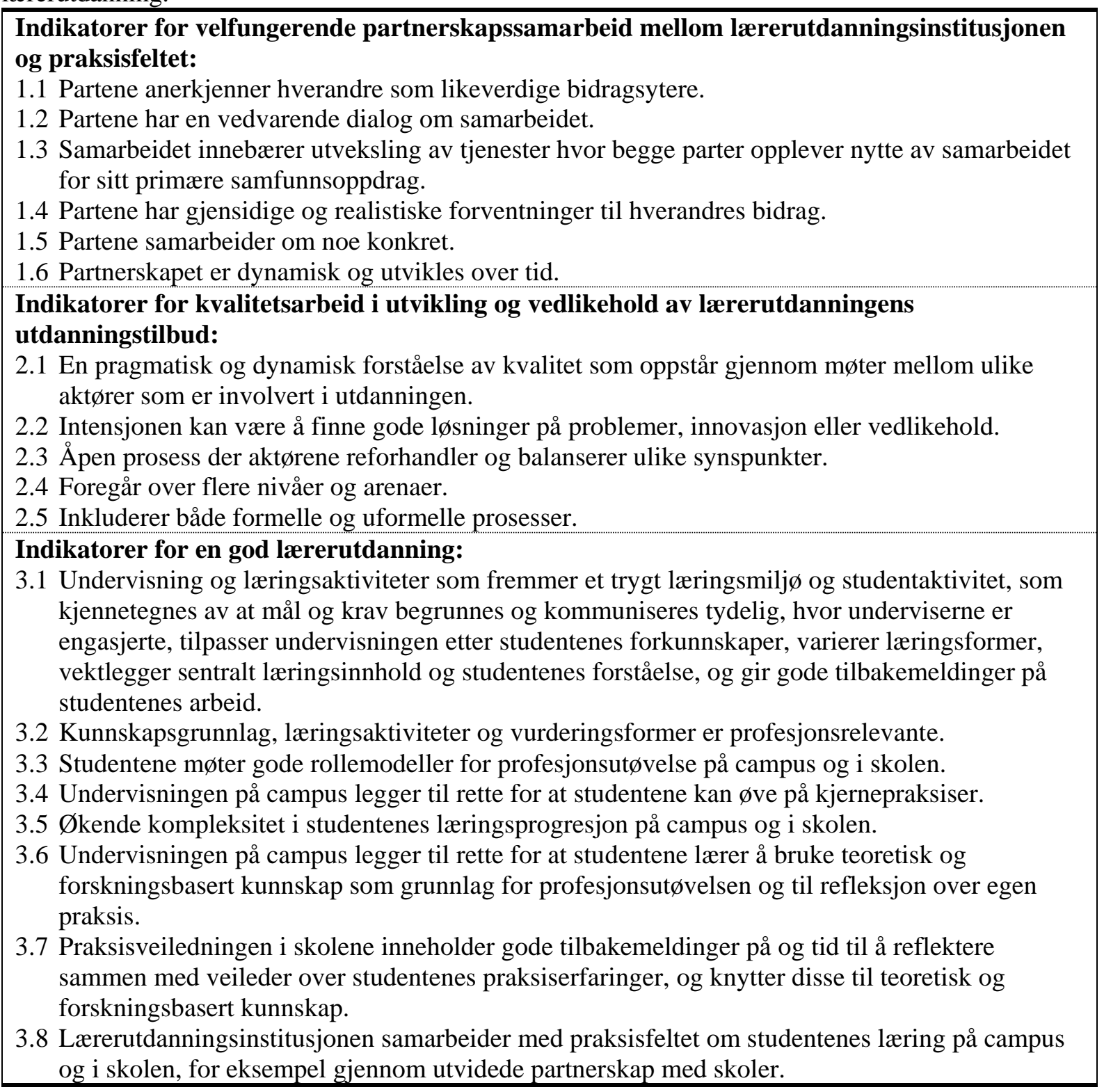

\section{Metode og kontekstbeskrivelse}

I denne artikkelen redegjør vi for og analyserer fem eksempler på aktiviteter i universitetsskolesamarbeidet ved UiO. Disse eksemplene er samarbeid om:

- utvikling og revisjon av en intensjonsavtale om samarbeid,

- styring og ledelse av lærerutdanningen,

- utvikling og revisjon av det femårige Lektorprogrammet,

- utvikling, revisjon og gjennomføring av det integrerte profesjonsfaget, og

- utvikling, revisjon og gjennomføring av mentorprogrammet. 
De enkelte eksemplene analyseres i lys av indikatorer på velfungerende partnerskap, kvalitetsarbeid i utvikling og vedlikehold av utdanningstilbud og god lærerutdanning, se tabell 1. I tråd med en design-basert forskningsmetode (Anderson \& Shattuck, 2012) er hensikten med analysen å forbedre praksis. Vi ønsker gjennom analysen av eksemplene å identifisere hvordan universitetsskoler kan bidra i arbeid med kvalitetsutvikling av lærerutdanningen. Denne kunnskapen kan brukes både til videreutvikling av UiOs eget universitetsskolesamarbeid og av andre lærerutdanningsinstitusjoner som er i startgropa med å utforme utvidede partnerskap med universitets-/lærerutdanningsskoler og barnehager. Som grunnlag for å beskrive de fem eksemplene benytter forfatterne egen kjennskap til universitetsskolesamarbeidet ved $\mathrm{UiO}$ og de nedtegnelser som finnes i rapporter, møteprotokoller, evalueringer, arbeidsdokumenter, program- og emnebeskrivelser, medieoppslag og tidligere forskningspublikasjoner. En fullstendig oversikt over det skriftlige datagrunnlaget gis i tabell 2, som er plassert som eget vedlegg til artikkelen.

For å forstå eksemplene fra universitetsskolesamarbeidet ved UiO gir vi som et bakteppe først en kort beskrivelse av lærerutdanningene ved UiO med særlig vekt på Lektorprogrammet, og deretter en historisk oversikt over utviklingen av samarbeidet med universitetsskoler.

\section{Lærerutdanningene ved Universitetet i Oslo}

UiO tilbyr to typer lærerutdanning: Praktisk-pedagogisk utdanning (PPU) og Lektorprogrammet, et integrert femårig masterprogram. PPU tilbys som heltidsstudium, deltidsstudium og skolebasert studium (Teach First) ${ }^{2}$. PPU heltid har to studieemner, hvert på 30 studiepoeng. PPU deltid, som tilbys over tre semestre, har to studieemner på henholdsvis 20 og 40 studiepoeng. Lektorprogrammet har siden oppstart i 2003 vært tilbudt gjennom et samarbeid mellom fem fakulteter: Det humanistiske fakultet (HF), Det matematisk-naturvitenskapelige fakultet (MN), Det samfunnsvitenskapelige fakultet (SV), Det teologiske fakultet (TF) og Det utdanningsvitenskapelige fakultet (UV). Studieprogrammet er i dag inndelt i 5 studieretninger med 48 ulike studieløp. Studiemodellene for studieretningen i realfag og for humaniora-samfunnsfag (HumSam) er illustrert i figur 1. 100 dager med praksis er integrert i profesjonsfaglige emner og fordelt over fire av fem år. ProTed har i samarbeid med universitetsskolene utviklet en profesjonsrettet mentorordning som tilbys alle lektorstudenter fra og med første semester.

\footnotetext{
${ }^{2}$ PPU Teach First Norway tilbys gjennom et samarbeid med Utdanningsetaten i Oslo og Equinor, der ILS sertifiserer deltagerne gjennom et skolebasert utdanningsløp på deltid.
} 


\begin{tabular}{|c|c|c|c|c|}
\hline \multirow[b]{3}{*}{9} & \multirow[b]{3}{*}{15} & \multicolumn{3}{|c|}{ Studiemodell realfag } \\
\hline & & Egr 11 & Ero 11 & twpons \\
\hline & & Fagdid. 1 & Fagdid .1 & Fagdid. 1 \\
\hline 8 & & Fag 1/ & Fag 1/ & $\begin{array}{c}\text { Fag 1/ } \\
\text { Fagdid. 1 }\end{array}$ \\
\hline 7 & 45 & \multicolumn{3}{|c|}{ Profesjonsfaget (PROF4045) } \\
\hline 6 & 25 & Fag 2 & \multicolumn{2}{|c|}{$\begin{array}{c}\text { Profesjonsfaget } \\
\text { (PROF3025) }\end{array}$} \\
\hline 5 & & Fag 2 & Fag 1 & Fag 1 \\
\hline 4 & & Fag 2 & Fag 1 & Fag 1 \\
\hline 3 & 15 & Fag 2 & Fag 1 & $\begin{array}{c}\text { Prof.faget } \\
\text { (PROF1015) }\end{array}$ \\
\hline 2 & & Fag 2 & Fag 1 & Fag 1 \\
\hline 1 & & Fag 2 & Fag 1 & Fag 1 \\
\hline Sem. & $\begin{array}{l}\text { Dager } \\
\text { praksis }\end{array}$ & 10 st.poeng & 10 st.poeng & 10 st.poeng \\
\hline
\end{tabular}

Studiemodell HumSam

\begin{tabular}{|c|c|c|}
\hline \multicolumn{3}{|c|}{ Masteroppgave 30 studiepoeng } \\
\hline $\begin{array}{c}\text { Fag 1 / } \\
\text { Fagdid. 1 }\end{array}$ & $\begin{array}{c}\text { Fag 1 / } \\
\text { Fagdid. 1 }\end{array}$ & $\begin{array}{c}\text { Fag 1 / } \\
\text { Fagdid. 1 }\end{array}$ \\
\hline $\begin{array}{c}\text { Fag 1 / } \\
\text { Fagdid. 1 }\end{array}$ & $\begin{array}{c}\text { Fag 1 / } \\
\text { Fagdid. 1 }\end{array}$ & $\begin{array}{c}\text { Fag 1 / } \\
\text { Fagdid. 1 }\end{array}$ \\
\hline \multicolumn{3}{|c|}{ Profesjonsfaget (PROF4045) } \\
\hline Fag 1 & \multicolumn{2}{|c|}{$\begin{array}{r}\text { Profesjonsfaget } \\
\text { (PROF3025) }\end{array}$} \\
\hline Fag 1 & Fag 1 & Fag 1 \\
\hline Fag 1 & Fag 1 & Fag 1 \\
\hline Fag 1 & Fag 1 & $\begin{array}{c}\text { Prof.faget } \\
\text { (PROF1015) }\end{array}$ \\
\hline Fag 2 & Fag 2 & Fag 2 \\
\hline Fag 2 & Fag 2 & Fag 2 \\
\hline 10 st.poeng & 10 st.poeng & 10 st.poeng \\
\hline
\end{tabular}

Figur 1. Lektorprogrammet, eksempel på studiemodeller. Venstre kolonne angir at den profesjonsrettede mentorordningen løper gjennom hele studiet. Kolonne nummer to fra venstre angir semestrene i det femårige studiet. Neste kolonne angir antall dager praksis i skolen per semester. I semestrene 3, 6 og 7 er praksis integrert i profesjonsfaget; i semester 9 er praksis integrert i et masteremne (Fag 1 eller Fagdidaktikk 1).

Vi gir en kort historisk oversikt over ulike perioder av samarbeidet, før vi redegjør for eksempler fra universitetsskolesamarbeidet som viser hvordan universitetsskolene har bidratt til utvikling av dagens studietilbud i Lektorprogrammet.

\section{Utvikling av universitetsskolesamarbeidet ved $\mathrm{UiO}$}

Institutt for lærerutdanning og skoleforskning (ILS) har lang erfaring fra samarbeid med skoler om lærerstudenters praksis. Siden 2009 er dette samarbeidet blitt videreutviklet gjennom en utvidet partnerskapsmodell med utvalgte universitetsskoler. Samarbeidet med universitetsskolene har gått gjennom flere faser før det nå er etablert som en varig samarbeidsstruktur. I de første årene (2009-2011) ble et tettere samarbeid etter modell fra universitetsklinikkene utforsket i samarbeid med Stovner videregående skole som ble Norges første universitetsskole (se omtale i Akers Avis Groruddalen 14. juni 2009; Ottersen, 2011). Denne samarbeidsstrukturen ble utvidet i 2011 med et pilotprosjekt kalt «Universitetsskole UiO», der 13 skoler ble tildelt status som universitetsskole for perioden 2011-2015 (Ottersen, 2011). Etter en vurdering av erfaringene gjort i det første året av pilotprosjektet, besluttet det daværende programrådet for Lektorprogrammet at ILS skulle ta over ansvaret for pilotprosjektet våren 2012 (ILS, 2012). I 2014 fikk ILS tildelt strategiske utviklingsmidler for tre år (2015-2017) til videreføring av universitetsskoleprosjektet. I 2015 ble samarbeidet utvidet fra de opprinnelige 13 pilotskolene, som rekvalifiserte seg, til å omfatte 21 skoler (Stølen \& Mo, 2018). I 2017 besluttet Universitetsstyret at den midlertidige strategiske utviklingsressursen til universitetsskolesamarbeidet skulle inngå som en varig øremerket tildeling til dette samarbeidet. Fra og med 2018 ble derfor UiOs utvidede partnerskapsmodell med universitetsskoler etablert som en fast 
samarbeidsstruktur (Stølen \& Mo, 2018), se figur 2 for en visualisering av periodene med partnerskap med universitetsskoler ved UiO.

\begin{tabular}{cccc}
$\begin{array}{c}\text { Norges første } \\
\text { universitetsskole }\end{array}$ & $\begin{array}{c}\text { Pilotprosjekt } \\
\text { 13 skoler }\end{array}$ & $\begin{array}{c}\text { Universitetsskoleprosjektet } \\
\text { 21 skoler }\end{array}$ & $\begin{array}{c}\text { Universitetsskolesamarbeid } \\
\text { 18 skoler }\end{array}$ \\
\hline $2009-2011$ & $2011-2015$ & $2015-2018$ & $2018-2022$ \\
\hline \multicolumn{4}{c}{ Samarbeid om utvikling, forvaltning og gjennomføring }
\end{tabular}

Figur 2. Visualisering av periodene av partnerskap med universitetsskoler ved UiO.

ILS har i dag partnerskapsavtaler med 125 partnerskoler. Av disse har $18 \mathrm{i}$ perioden 2018-2022 fătt status som UiOs universitetsskoler (Stølen \& Mo, 2018). Disse skiller seg fra de andre partnerskolene ved blant annet å være interesserte i et utvidet samarbeid og inngå i et forpliktende, gjensidig partnerskap med UiO (ILS, 2018). Partnerskoler har i et historisk perspektiv alltid hatt en særs viktig oppgave i samarbeidet om å gjennomføre lærerutdanningene gjennom veiledning og vurdering av studenter i forbindelse med praksisopplæringen i studieprogrammene. Denne funksjonen er fortsatt like viktig og har i de siste årene fått en forsterket status ved at praksisveiledere i skolen defineres som lærerutdannere på lik linje med fagmiljøene ved UH-institusjonene. ILS har også en lang tradisjon for å engasjere enkeltlærere fra våre partnerskoler til å bidra i forbindelse med praksispåhør, sensur og i noen tilfeller undervisning på campus. Med innføringen av samarbeid med universitetsskoler ble delte stillinger, primært gjennom en frikjøpsmodell, vanligere og et viktig bidrag i gjennomføringen av studieprogrammene.

\section{Universitetsskolesamarbeid ved Universitetet i Oslo}

Erfaringer fra enkelte sider ved universitetsskolesamarbeidet ved UiO er omtalt i tidligere publikasjoner (Engelien, Eriksen \& Jakhelln, 2015; Hatlevik, Hunskaar \& Eriksen, 2020; Hatlevik \& Lejonberg, 2019; Hunskaar \& Borge, 2015; Hunskaar \& Eriksen, 2019; Jakhelln, Lund \& Vestøl, 2017; Lejonberg, Elstad \& Hunskaar, 2017; Lund \& Eriksen, 2016; Vestøl, Lund \& Jakhelln, 2015). Disse publikasjonene har omtalt innholdet i den første intensjonsavtalen mellom partene og gitt eksempler både på samarbeid om utvikling og gjennomføring av studietilbud på campus og i praksis, og på forsknings- og utviklingsarbeid i skolen. Imidlertid har de tidligere publikasjonene ikke redegjort for samarbeidet om utvikling og revisjon av intensjonsavtalen, og i liten grad hatt fokus på hvordan universitetsskolene deltar i styring og ledelse i lærerutdanningen og i utvikling og revisjon av program- og emneplaner. I det følgende gir vi fem eksempler fra universitetsskolesamarbeidet ved UiO som omhandler de nevnte aktivitetene, og analyserer disse i lys av indikatorer for velfungerende partnerskap (jf. punktene 1.1-1.6 i tabell 1) og kvalitetsarbeid i utvikling og vedlikehold av utdanningstilbud (jf. punktene 2.1-2.5). I analysen trekker vi også frem hvordan 
universitetsskolenes bidrag til kvalitetsarbeidet relaterer seg til indikatorer på en god lærerutdanning (jf. punktene 3.1-3.8).

\section{Eksempel 1: Samarbeid om utvikling og revisjon av en intensjonsavtale}

Premisset for å inngå i et utvidet partnerskap med universitetsskoler, er at universitet og skole vurderer hverandre som viktige bidragsytere til henholdsvis lærerutdanning og skoleutvikling ved at de representerer ulik, men komplementær kunnskap (jf. punkt $1.1 \mathrm{i}$ tabell 1). Dette gjenspeiles i daværende leder av universitetsskoleprosjektet, Tone Dyrdal Solbrekke, sin uttalelse til Uniforum i 2011:

Formålet med universitetsskolesatsingen er å styrke både Lektorprogrammet ved UiO og skolene gjennom bedre integrering av praksis og de ulike elementene i utdanningen, men også kompetansen og det pedagogiske utviklingsarbeidet ved skolene. Dette vil lede til bedre og mer omfattende kompetanse blant studentene når de har fullført studiene sine, og bedre pedagogisk kvalitet ved skolene. (Uniforum, 2011)

Tilsvarende uttrykte rektor Gro Flaten ved Bjerke videregående skole i 2011 hvordan skolene på sin side hadde forventning om både hva universitetet kunne bidra med til skolene, og hvordan de kunne bidra inn i lærerutdanningen:

Flaten forteller at gjensidig utveksling av erfaringer, identifisering av forskningsbehov og engasjement i forsknings- og utviklingsarbeid er viktige begrunnelser for skolens $\emptyset$ nske om å bli universitetsskole. [...] Flaten ser for seg at skolen kan bidra med kompetanse og ressurser innenfor utvikling av læringsmiljø og klasseledelse - som universitetsskole. (Akers Avis Groruddalen, 2011)

Tidligere publikasjoner (Hunskaar \& Eriksen, 2019; Hatlevik, Hunskaar \& Eriksen, 2020) har redegjort for at selv om intensjonen ved oppstarten av universitetsskolesamarbeidet var i tråd med både det at partene anerkjenner hverandre som likeverdige bidragsytere (jf. punkt 1.1) og at samarbeidet skulle innebære utveksling av tjenester hvor begge parter opplevde nytte av samarbeidet for sitt primære samfunnsoppdrag (jf. punkt 1.3), viste det seg tidlig at det var en utfordring å forene akademias interesser for forskning og skolenes behov for FoUarbeid. I 2012 uttrykte universitetsskolene skuffelse over at de ikke hadde fått den tilgangen til universitetets faglige ressurser som de ble forespeilet ved oppstarten av pilotperioden fra 2011. Med tilgang til faglige ressurser siktes det til samarbeid om FoU-arbeid i skolen og kunnskap formidlet gjennom for eksempel forelesninger for lærere eller elever ved skolene (Hunskaar \& Eriksen, 2019). Universitetsskolenes skuffelse over samarbeidet aktualiserte behovet for dialog om hva partene kan forvente av samarbeidet (jf. punkt 1.2). I 2012 ble det som resultat av dialogen mellom ILS og representanter for de daværende universitetsskolene opprettet et samarbeidsutvalg med representanter fra universitetsskolene 
og universitetet som utarbeidet en intensjonsavtale. I intensjonsavtalen fra 2012 ble hensikten med universitetsskoleprosjektet formulert til å være et «samarbeid mellom universitetet og skolene om:

- Utvikling av lærerutdanningen

- Forsknings- og utviklingsarbeid i skolene

- Utvikling av lærerstudentenes praksis»

I 2019 ble intensjonsavtalen revidert og ordlyden om hensikten med det utvidede partnerskapet er endret til:

«Målsettingen med samarbeidet er å:

- Utvikle kvaliteten i skolen og i høyere utdanning for å styrke elevers og studenters læring

- Videreutvikle lærerutdanningene, og skape gode modeller for lærerstudentenes praksis

- Øke samarbeidet om forsknings- og utviklingsarbeid i skolene»

Formuleringene i avtalen fra 2012 og i den reviderte fra 2019 gjenspeiler en intensjon om at samarbeidet skal innebære utveksling av tjenester hvor begge parter opplever nytte av samarbeidet for sitt primære samfunnsoppdrag (jf. punkt 1.3) og at en samarbeider om noe konkret (jf. punkt 1.5). I intensjonsavtalen er det også nedfelt punktvis hva partene kan forvente av hverandre. Også disse er revidert i 2019 med bakgrunn i innspill fra representanter for skoleeiere og universitetsskoler. Disse punktene uttrykker således gjensidige og realistiske forventninger til hva hver part kan bidra med i samarbeidet (jf. punkt 1.4).

Prosessen for utforming av intensjonsavtalen i 2012 og revidering av denne $\mathrm{i}$ 2019 foregikk gjennom samtaler og møter mellom partene på ulike arenaer (jf. punkt 2.4). I 2019 ble et utkast til den reviderte avtalen diskutert på et møte mellom representanter for ILS, en av skoleeierne og en av skolene. Deretter ble et videre bearbeidet utkast diskutert i samarbeidsutvalget. Samarbeidsutvalget er et forum for informasjonsdeling og samtaler om universitetsskolesamarbeidet hvor universitetsskoler, skoleeiere, studenter og ILS er representert ${ }^{3}$. Revideringen av intensjonsavtalen gjenspeiler at utforming av formuleringene $\mathrm{i}$ intensjonsavtalen om hensikten med partnerskapet utvikles over tid (jf. punkt 1.6) og er blitt til som et resultat av diskusjoner mellom partene hvor ulike synspunkter er tatt hensyn til (jf. punkt 2.3). Disse diskusjonene har foregått på flere arenaer (jf. punkt 2.4). Eksemplene 2-5 som presenteres nedenfor, er eksempler på konkrete aktiviteter som det samarbeides om (jf. punkt 1.5).

\footnotetext{
${ }^{3}$ Hensikten med samarbeidsutvalget er å orientere partene om aktiviteter som er relevante for partnerskapet, diskutere ideer og prinsipielle forhold og være en arena hvor partene kan komme med innspill til utvikling av partnerskapet.
} 


\section{Eksempel 2: Samarbeid om styring og ledelse av lærerutdanningen}

Med etableringen av universitetsskolesamarbeidet med Stovner videregående skole i 2009 ble det også innført faste strukturer for samarbeid om forvaltning av lærerutdanningen. Dette gir seg utslag i at representanter for universitetsskolene er formelt valgt til fakultetsstyret og formelt oppnevnt til instituttstyret ved ILS og til alle program- og fagråd. De er også involvert i større og mindre utviklingsprosjekter i utdanningene gjennom å delta i midlertidige utvalg som opprettes i forbindelse med utvikling eller revisjon av program- og emneplaner, undervisnings- og vurderingsformer og nye praksisformer. På disse arenaene kan universitetsskolene og representanter for fagmiljøene og studentene komme med sine synspunkt og anbefalinger når det gjelder tiltak for videreutvikling av lærerutdanningen. På denne måten gis ulike aktører som er involvert i utdanningen mulighet til å bidra $\mathrm{i}$ arbeid med kvalitetsutvikling av lærerutdanningen på ulike arenaer hvor det tas strategiske viktige beslutninger om prioriteringer og innsatsområder (jf. punkt $2.4 \mathrm{i}$ tabell 1). Ved at skolene er representert i de nevnte fora, kan de gi lærerutdanningen kunnskap om skolenes vurdering av de enkelte saksforhold som tas opp (jf. punkt 2.3). Likeledes gir det skolene som er representert, kunnskap om hvilke saker som opptar lærerutdanningen. For lærerutdanningen bidrar dette til å legge til rette for at forvaltningen av lærerutdanningen har god kontakt med praksisfeltet (jf. punkt 3.8), og dermed kan treffe beslutninger som bidrar til utvikling av en profesjonsrelevant lærerutdanning (jf. punkt 3.2).

\section{Eksempel 3: Samarbeid om utvikling og revisjon av det femårige Lektorprogrammet}

Ved etableringen av Lektor- og adjunktprogrammet i 2003 ble det skapt en ny type utdanning der den ettårige årsenheten PPU ble lagt inn i studieløpet som kvalifiserte studentene til å bli enten adjunkter eller lektorer. I en programevaluering i 2008 ble det nedsatt en egen revisjonskomité som skulle fremme forslag til strukturelle og organisatoriske endringer ved programmet, i den hensikt å utvikle programmet $\mathrm{i}$ retning av et profesjonsstudium. Resultatet av komitéens arbeid ble at programmet ble definert som et femårig masterprogram og skiftet navn til Lektorprogrammet, en utvidelse av praksisopplæringen og det ble uttrykt et $\emptyset$ nske om et tettere samarbeid med praksisfeltet (UiO, 2009). I forlengelsen av dette inngikk ILS i 2009 en avtale med Stovner videregående skole om å utvikle et tettere samarbeid om studentenes praksis i skolen (jf. punkt $2.2 \mathrm{i}$ tabell 1). Daværende rektor ved skolen deltok i et utredningsarbeid som kartla hvordan en ny struktur for praksis i programmet kunne bidra til å skape et tydeligere profesjonsrettet studieløp. Skolen satset på profesjonsutvikling av egne lærere ved å legge til rette for at flere lærere fikk formell veilederkompetanse, slik at de ble 
enda bedre rustet til å motta flere studenter i praksis (jf. punkt 1.3). Omfanget av praksis i Lektorprogrammet ble $\varnothing \mathrm{kt}$ fra 60 dager $^{4}$ til 75 dager. Det ble utviklet praksiskort som konkretiserte hva som skulle være fokus for læringsprosessen i de ulike praksisemnene (periodene). De nye praksisemnene og de tilhørende praksiskortene la til rette for å skape en bedre forståelse mellom skolene og ILS av hva praksis skulle være i de ulike fasene i studentens læringsløp (jf. punkt 3.8). Praksiskortene er siden revidert i samarbeid med universitetsskolene (jf. punkt 2.3).

\section{Eksempel 4: Samarbeid om utvikling, revisjon og gjennomføring av det integrerte profesjonsfaget}

En omfattende revisjon av studiedesignet for PPU ble igangsatt i 2010. I rapporten fra revisjonskomiteen (ILS, 2011) ble det skissert et Program for Utdanning av Pedagogiske faglærere ved ILS, også kalt PUPILS-modellen. Et viktig premiss som lå til grunn for denne modellen, var å skape progresjon for læring i fag og praksis gjennom fire overordnede temaområder og tett samarbeid med praksisfeltet. I samarbeid med seks universitetsskoler ble PUPILS-modellen konkretisert, videreutviklet og prøvd ut høsten 2012 og våren 2013 (jf. punktene 2.2 og $2.3 \mathrm{i}$ tabell 1). Samarbeidet bidro blant annet til å utvikle pilotemner som konkretiserte intensjonene i PUPILS-modellen i tilknytning til de fire overordnede temaområdene i de nye studieemnene, se figur 3.

\begin{tabular}{|l|l|l|l|l|}
\hline Studiedesign & Temaområde 1 & Temaområde 2 & Temaområde 3 & Temaområde 4 \\
\hline PUPILS & $\begin{array}{l}\text { Observasjon og } \\
\text { læring }\end{array}$ & $\begin{array}{l}\text { Klasseroms- } \\
\text { organisering } \\
\text { og læring }\end{array}$ & Vurdering og læring & $\begin{array}{l}\text { Design for } \\
\text { inkluderende } \\
\text { klasserom }\end{array}$ \\
\hline $\begin{array}{l}\text { Pilotemner } \\
\text { H12-V13 }\end{array}$ & $\begin{array}{l}\text { Undervisning og } \\
\text { læring }\end{array}$ & $\begin{array}{l}\text { Klasse- og } \\
\text { undervisningsledelse }\end{array}$ & Vurdering & Differensiering \\
\hline $\begin{array}{l}\text { Nåværende } \\
\text { emner }\end{array}$ & $\begin{array}{l}\text { Undervisning og } \\
\text { læring }\end{array}$ & Klasseledelse & Vurdering & Tilpasset opplæring \\
\hline
\end{tabular}

Figur 3. Oversikt over hvordan de overordnede temaområdene i PUPILS-modellen er konkretisert og videreutviklet i dialog med universitetsskolene.

En tydelig tematisering av læringsinnholdet i PPU hadde til hensikt å skape et helhetlig læringsløp og slik motvirke tidligere utfordringer knyttet til fragmentering. Tematiseringen ga en tydelig profesjonsprofil ved å handle om kjernepraksiser i læreryrket (jf. punkt 3.4). De nye emnene som ble utviklet i samarbeid med universitetsskolene i forlengelsen av arbeidet med PUPILS-modellen, fikk læringsutbyttebeskrivelser og vurderingsformer som integrerte fagdidaktikk,

\footnotetext{
${ }^{4}$ I henhold til daværende forskrift for PPU (Kunnskapsdepartementet, 2005), skulle PPU inneholde minimum 60 dager obligatorisk praksis.
} 
pedagogikk og praksis (jf. punktene 3.2 og 3.8). I samarbeid med fire universitetsskoler ble det også utviklet en ny læringsaktivitet, Dialogseminarer, som skulle bidra til å styrke koblingen mellom teori og praksis (jf. punktene 3.6, 3.7 og 3.8). Dialogseminar er en møteplass mellom studenter, praksisveiledere fra skolene og vitenskapelig tilsatte med undervisningsansvar. I seminaret bringer studentene inn case fra praksis om en situasjon de opplever som utfordrende og som de ønsker å få de andres innspill på (for en nærmere beskrivelse se Hatlevik, Hunskaar \& Eriksen, 2020). Samarbeidet med universitetsskolene om utviklingen av det nye studiedesignet ble også nært knyttet til utvikling av ny struktur for praksis i PPU der studentene i større grad enn tidligere skulle skifte mellom læringsaktiviteter på campus og i skolen. Nesodden videregående skole, som er en av universitetsskolene, tok initiativ til å utvikle en modell for en storgruppepraksis gjennom en felles intensiv praksisuke, som nå er del av regulær drift og tilbys tidlig i første semester av PPU og Lektorprogrammets første profesjonsemne (PROF1015) (for en nærmere beskrivelse se Hatlevik, Hunskaar \& Eriksen, 2020).

Siden piloteringen av det nye integrerte profesjonsfaget har studieemnene $\mathrm{i}$ PPU og Lektorprogrammet vært gjennom flere revisjoner hvor representanter for universitetsskolene har bidratt (jf. punkt 2.3) ved å delta i ulike prosjekt- og arbeidsgrupper, men også gjennom å være representert i fagråd hvor emneplaner vedtas (jf. punkt 2.4). Men det grunnleggende studiedesignet som ble utviklet i 2011-2012 med integrerte læringsutbyttebeskrivelser og eksamensformer, ligger fortsatt til grunn for PPU og i profesjonsfaget i Lektorprogrammet.

\section{Eksempel 5: Samarbeid om utvikling, revisjon og gjennomføring av mentorordning i Lektorprogrammet}

Høsten 2014 startet implementeringen av nye studiemodeller for Lektorprogrammet. I de nye studiemodellene var det første studieåret i sin helhet forbeholdt fagemner (fag $1 \mathrm{og} / \mathrm{eller}$ fag 2). Studentene har sitt innføringsemne i profesjonsfaget først i tredje semester, se figur 1. Tidligere tilbakemeldinger fra studentene tydet på at de hadde problemer med å identifisere hvilke andre studenter som også var lektorstudenter, og at de i liten grad identifiserte seg selv som lektorstudenter (Hatlevik \& Lejonberg, 2019). Det var derfor ønskelig å iverksette et programtiltak som både ville tydeliggjøre programmets profesjonsprofil og kunne styrke studentenes tilknytning til Lektorprogrammet gjennom å $\varnothing$ ke kulltilhørigheten (jf. punkt $2.2 \mathrm{i}$ tabell 1). I samarbeid med representanter fra universitetsskolene ble det utviklet et konsept for en mentorordning for studentene som kunne gjennomføres i samarbeid med universitetsskolene. Den første piloten ble iverksatt høsten 2014 med det første studentkullet som begynte på det nye Lektorprogrammet (se figur 1). I 2016 ble ordningen evaluert, og det ble nedsatt en prosjektgruppe med representanter fra ILS og universitetsskolene som videreutviklet ordningen. Den reviderte modellen for mentorordningen, Profesjonsrettet 
mentorordning (PROMO), er siden høsten 2016 tilbudt studenter på Lektorprogrammet (for en detaljert presentasjon av PROMO, se Hatlevik \& Lejonberg, 2019). Mentorene er til daglig lærere i skolen med veilederutdanning, hovedsakelig ved nåværende eller tidligere universitetsskoler, med samme fag som studentene i sin gruppe. Tema og emneplan for hvert emne ble utarbeidet av prosjektgruppa. Den videre utviklingen av tematisk innhold og utarbeiding av opplegg for samlingene utvikles og revideres av mentorene med støtte fra prosjektgruppa (jf. punkt 2.3). Det avholdes et felles planleggings- og evalueringsmøte hvert semester hvor mentorene diskuterer og planlegger opplegg for samlingene. Disse oppleggene legger den enkelte mentor til grunn for detaljplanlegging og gjennomføring av samlingene.

PROMO er et eksempel på et undervisningstilbud hvor representanter for universitetsskoler har vært med i utvikling og revidering av emneplaner og innhold, og står for gjennomføring av tilbudet på campus. I likhet med mentorene i PROMO er også ansatte i universitetsskolene frikjøpt i $10-20 \%$ for å delta i andre deler av undervisningstilbudet på campus. I det første profesjonsemnet $\mathrm{i}$ Lektorprogrammet, PROF1015, se figur 1, er seminarlederne frikjøpte lærere med veilederutdanning fra nåværende eller tidligere universitetsskoler (for en nærmere beskrivelse se Hatlevik, Hunskaar \& Eriksen, 2020). Bruk av frikjøpte representanter for universitetsskolene i undervisningstilbudet på campus er eksempler på hvordan universitetsskolesamarbeidet kan forsterke Lektorprogrammets profesjonsprofil (jf. punkt 3.2), gi studentene gode rollemodeller for hva det vil si å være en profesjonell lærer (jf. punkt 3.3) og fremme integrasjon mellom undervisningstilbud på campus og praksisopplæring i skolen (jf. punkt 3.8).

De fem eksemplene fra universitetsskolesamarbeidet ved UiO viser at skolene har deltatt i utforming av hva samarbeidet skal handle om og $\mathrm{i}$ arbeidet med kvalitetsutviklingen av lærerutdanningen ved UiO. Avslutningsvis kommenterer vi hvordan eksemplene bidrar med kunnskap om hvordan universitetsskoler kan være viktige aktører i kvalitetsutvikling av lærerutdanningen, mulige utfordringer i samarbeidet og behov for videre studier.

\section{Avsluttende kommentar}

Etablering av nye, utvidede partnerskap mellom institusjoner som tilbyr lærerutdanning, skoler/barnehager og skoleeiere, er av Kunnskapsdepartementet (2017) løftet frem som et sentralt strategisk grep for å styrke kvaliteten på praksisopplæringen i lærerutdanningen og fremme FoU-kompetansen i skolene. I denne artikkelen har vi hatt fokus på lærerutdanningen og vist hvordan samarbeid $\mathrm{i}$ utvidede partnerskap kan bidra til kvalitetsarbeid knyttet til andre aspekter ved lærerutdanningen enn bare studentenes praksis i skolene. Vi har redegjort for fem eksempler fra UiOs samarbeid med universitetsskoler. Disse eksemplene er 
analysert i lys av indikatorer for velfungerende partnerskapssamarbeid mellom lærerutdanningsinstitusjon og praksisfeltet, kvalitetsarbeid relatert til utvikling og vedlikehold av utdanningstilbud og god lærerutdanning, se tabell 1. Indikatorene kan også brukes av andre institusjoner ved utvikling av nye partnerskap og til analyse av eksisterende partnerskap mellom en lærerutdanningsinstitusjon og praksisfeltet.

Erfaringer fra startfasen av UiOs samarbeid med universitetsskoler illustrerer betydningen av alle seks indikatorene på velfungerende partnerskap (se tabell 1, punktene 1.1-1.6) som tidligere forskning har identifisert (Lillejord \& Børte, 2014). Analysen viser hvordan partene i 2011 uttrykte $\emptyset$ nsker for samarbeidet som var i tråd med to av indikatorene for velfungerende partnerskap, nemlig at partene anerkjenner hverandre som likeverdige bidragsytere (jf. punkt 1.1) og at samarbeidet innebærer utveksling av tjenester hvor begge parter opplever nytte av samarbeidet for sitt primære samfunnsoppdrag (jf. punkt 1.3). Imidlertid viste de tidlige erfaringene at gode hensikter ikke var tilstrekkelig og at det var behov for en dialog om hva samarbeidet skulle innebære (jf. punkt 1.2). Dialogen resulterte i utarbeiding av en intensjonsavtale i fellesskap, som uttrykte både målsetning for og hva det er realistisk at partene kan forvente av hverandre (jf. punkt 1.4) og områder for samarbeidet (jf. punkt 1.5).

Redegjørelsen for universitetsskolenes deltagelse i styring og ledelse av lærerutdanningen ved $\mathrm{UiO}$ viser at skolene gjennom denne typen deltagelse kan gi lærerutdanningen kunnskap om skolenes synspunkt på de enkelte saksforhold som tas opp (jf. punkt 2.3). Det bidrar til at forvaltningen av lærerutdanningen har god kontakt med praksisfeltet (jf. punkt 3.8) slik at det kan treffes beslutninger som bidrar til utvikling av en profesjonsrelevant lærerutdanning (jf. punkt 3.2).

Analysene av eksemplene om samarbeid om utvikling og revidering av Lektorprogrammet, det integrerte profesjonsfaget og mentorordningen viser hvordan lærerutdanningen har utfordringer de ønsker å løse (jf. punkt 2.2). Samarbeidet om å løse de enkelte utfordringene kan beskrives som en prosess der begge parter bidrar gjennom å komme med innspill og diskutere de ulike synspunktene (jf. punkt 2.3). Resultatet av samarbeidet er en revisjon av tidligere tilbud og i enkelte tilfeller en innovasjon i form av ny praksisform og et nytt tilbud til studentene som mentorordning. Eksemplene viser også et samarbeid som er i stadig utvikling (jf. punkt 1.6) ved at det gjennom årene er samarbeidet om en rekke ulike prosjekter og at samarbeidet foregår gjennom en kontinuerlig dialog på flere arenaer hvor ulike representanter bidrar (jf. punkt 2.4). Dette gjenspeiler en forståelse av at kvalitetsarbeid i utvikling og forvaltning av et utdanningstilbud innebærer en pragmatisk og dynamisk forståelse av kvalitet som oppstår i møte mellom ulike aktører som er involvert i utdanningen (jf. punkt 2.1). Eksemplene viser hvordan universitetsskolene kan delta i formelle prosesser relatert til arbeid med kvalitetsutvikling av lærerutdanningen (jf. punkt 2.5). Hvordan de kan delta i mer uformelle prosesser er imidlertid i liten grad belyst. Å kartlegge betydningen 
av uformelle prosesser i universitetsskolesamarbeidet vil være et interessant tema for videre studier.

Analysen av eksemplene indikerer at partnerskap tilsvarende det $\mathrm{UiO}$ har med universitetsskoler, kan bidra til å imøtekomme flere av indikatorene på en god lærerutdanning, som profesjonsrelevant kunnskapsgrunnlag, undervisning og vurderingsformer (jf. punkt 3.2), tilby studentene gode rollemodeller for profesjonsutøvelse (jf. punkt 3.3) og tett samarbeid med profesjonen om studentenes læring på campus og i skolen (jf. punkt 3.8). Eksempelet med samarbeid om utvikling av profesjonsfaget indikerer også at det på bakgrunn av samarbeidet er gjort grep i programplanen slik at studieprogrammet skal innebære $\varnothing$ ving på kjernepraksiser (jf. punkt 3.4), økende kompleksitet i studentenes læring på campus og i skolen (jf. punkt 3.5) og vektlegging av anvendelse av forskningsbasert kunnskap som grunnlag for profesjonsutøvelse og refleksjon over praksis (jf. punkt 3.6). I hvilken grad universitetsskolesamarbeid kan fremme andre aspekter ved god undervisning på campus (jf. punkt 3.1), og god praksisveiledning (jf. punkt 3.7), gir ikke datagrunnlaget som benyttes i denne artikkelen holdepunkt for å vurdere. Dette er viktige empiriske spørsmål som bør følges opp i videre studier som analyserer partenes og studentenes evalueringer av utdanningstilbudet i lærerutdanningen.

På bakgrunn av analysene har vi gruppert hvordan universitetsskoler kan bidra til samarbeid om kvalitetsarbeid i lærerutdanningen i tre aspekter: Samarbeid om 1) forvaltning, 2) utvikling og revidering, og 3) gjennomføring av lærerutdanningen. Disse tre aspektene ved samarbeidet står i et gjensidig påvirkningsforhold til hverandre og innebærer at skolenes deltagelse ikke reduseres til enkeltstående bidrag, men tar form av et systematisk og målrettet samarbeid for å fremme kvalitet i lærerutdanningen, se figur 4.

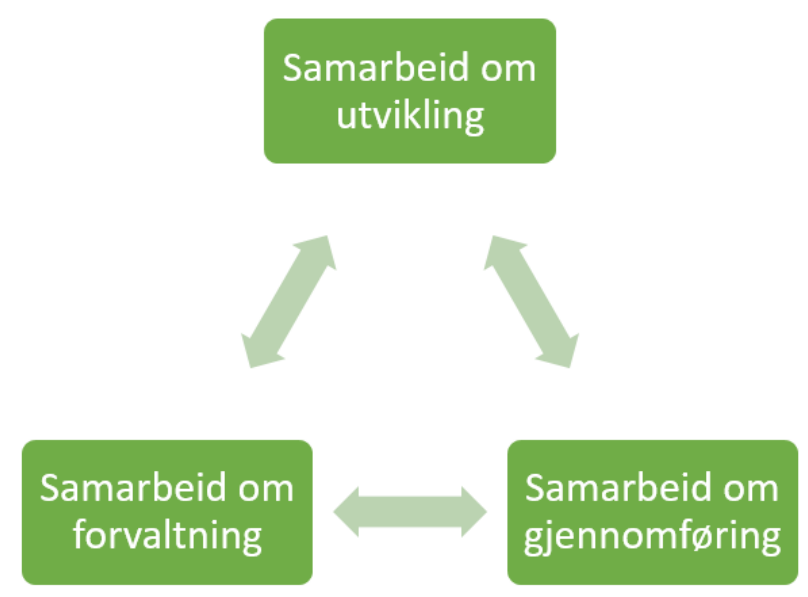

Figur 4. Illustrasjon av et gjensidig påvirkningsforhold mellom ulike former for samarbeid med universitetsskoler som kan fremme kvalitet i lærerutdanningen.

Imidlertid handler universitetsskolesamarbeid om mer enn bare kvalitetsutvikling av lærerutdanningen. I intensjonsavtalen for universitetsskolesamarbeidet ved $\mathrm{UiO}$ er det nedfelt at samarbeidet skal handle om både utvikling av lærerutdanningen og forsknings- og utviklingsarbeid i skolene. Figur 5 gir en visuell 
oversikt over hvilke områder UiO og universitetsskoler samarbeider om når det gjelder kvalitetsutvikling av lærerutdanningene og forsknings- og utviklingsarbeid i skolen.

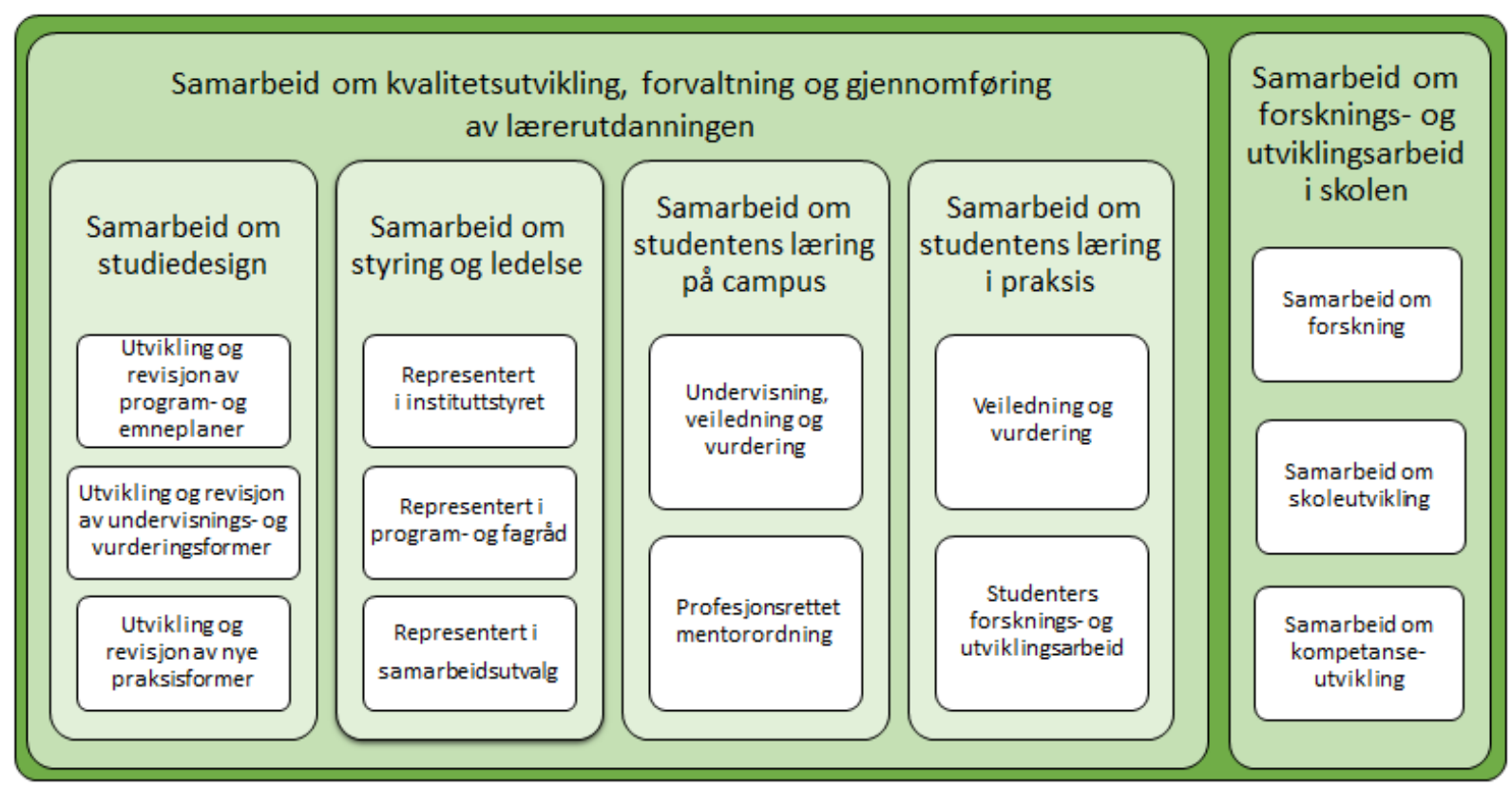

Figur 5. Oversikt over ulike sider ved universitetsskolesamarbeidet ved Universitetet i Oslo.

Som figur 5 visualiserer, har en stor del av universitetsskolesamarbeidet handlet om samarbeid om kvalitetsutvikling, gjennomføring og forvaltning av lærerutdanningen. Tidligere publikasjoner redegjør for samarbeidsprosjekter som er utviklet og gjennomført for å styrke skolenes FoU-kompetanse (Hatlevik, Hunskaar \& Eriksen, 2020; Hunskaar \& Borge, 2015; Hunskaar \& Eriksen, 2019; Eriksen, 2016). Imidlertid er det behov for videre studier som undersøker i hvilken grad skolene og skoleeier opplever at samarbeidet møter deres behov for forskningsog utviklingsarbeid. Det er også behov for studier av hvordan samarbeid om forsknings- og utviklingsarbeid kan bidra til at de vitenskapelig ansatte i lærerutdanningen $\varnothing$ ker sin kunnskap om praksis, og hvordan dette kan gjøre deres forskning og undervisning mer praksisrelevant.

En sentral utfordring for et utvidet partnerskapssamarbeid som er godt forbi etableringsfasen, og som har kommet langt i utvikling av lærerutdanningen, er hvordan opprettholde og videreutvikle samarbeidet fremover (jf. punkt $1.6 \mathrm{i}$ tabell 1). En mulighet for videreutvikling av samarbeidet er å dreie fokus mer over mot FoU-samarbeid med skolene. Imidlertid forutsetter dette at universitetet har vitenskapelig ansatte som $\emptyset$ nsker å bidra i prosjekter som er sammenfallende med skolenes interesser, og som ser nytten av et slikt samarbeid for egen forskning, undervisning og karriereutvikling. Altså er samarbeid om forskning og utviklingsarbeid i skolen mulig, men krevende når det gjelder både identifisering av sammenfallende interesser, motivering til deltagelse og finansiering av konkrete prosjekter. 


\section{Om forfatterne}

Ida Katrine Riksaasen Hatlevik er førsteamanuensis i pedagogikk og faglig leder av universitetsskolesamarbeidet ved Universitet i Oslo. Hennes forskningsinteresser omfatter blant annet partnerskap mellom lærerutdanningsinstitusjon og universitetsskoler, koherens og studiekvalitet i profesjonsutdanninger, studenters studieengasjement, og utvikling av profesjonskompetanse og profesjonsidentitet. Institusjonstilknytning: Institutt for lærerutdanning og skoleforskning, Universitetet i Oslo, Postboks 1099 Blindern, 0317 Oslo.

E-post: i.k.r.hatlevik@ils.uio.no

Kirsti Lyngvær Engelien er førstelektor i lærerutdanning og undervisningsleder ved Institutt for lærerutdanning og skoleforskning. Hennes forskningsinteresser omfatter blant annet partnerskap mellom lærerutdanningsinstitusjon og universitetsskoler, kvalitet i lærerutdanninger og design av undervisning og læring i teknologirike omgivelser.

Institusjonstilknytning: Institutt for lærerutdanning og skoleforskning, Universitetet i Oslo, Postboks 1099 Blindern, 0317 Oslo.

E-post: k.l.engelien@ils.uio.no

Doris Jorde er professor i naturfagdidaktikk og senterleder for ProTed - Senter for fremragende lærerutdanning - Universitet i Oslo. Hun har tidligere vært leder av Naturfagsenteret ved UiO. Som senterleder for ProTed arbeider hun med innovasjon i lærerutdanningen for trinn 8-13. Hennes forskningsinteresser omfatter organisering av og koherens i lærerutdanning ut fra både et system- og et studentperspektiv.

Institusjonstilknytning: Institutt for lærerutdanning og skoleforskning, Universitetet i Oslo, Postboks 1099 Blindern, 0317 Oslo.

E-post: doris.jorde@ils.uio.no

\section{Referanser}

Akers Avis Groruddalen (14. juni 2009). Norges første universitetsskole. https://groruddalen.no/nyheter/norges-forste-universitetsskole/19.10508

Anderson, T. \& Shattuck, J. (2012). Design-Based Research: A Decade of Progress in Education Research? Educational Researcher, 41(1), 16-25. https://doi.org/10.3102/0013189X11428813

Beck, C. \& Kosnik, C. (2002). Components of a good practicum placement: Student teacher perceptions. Teacher Education Quarterly, 29, 81-98.

Billett, S. \& Choy, S. (2013). Learning through work: emerging perspectives and new challenges. Journal of Workplace Learning, 25(4), 264-276. 
Breault, D. A. \& Breault, R. (2010). Partnerships for preparing leaders: what can we learn from PDS research? International Journal of Leadership in Education, 13(4), 437-454. https://www.tandfonline.com/doi/full/10.1080/13603120903215648?scroll=top\&needAcc $\underline{\text { ess }=\text { true }}$

Chickering, A. W. \& Gamson, Z. F. (1987). Seven principles for good practice in undergraduate education. AAHE Bulletin, March 1987, 3-7.

Darling-Hammond, L. \& Bransford, J. (red.) (2005). Preparing teachers for a changing world. What teachers should learn and be able to do. San Francisco, CA: Jossey-Bass.

Elken, M. \& Stensaker, B. (2018). Conceptualising 'quality work' in higher education. Quality in Higher Education, 24(3), 189-202. https://doi.org/10.1080/13538322.2018.1554782

Ellis, V. \& McNicholl, J. (2015). Transforming Teacher Education: Reconfiguring the Academic Work. London: Bloomsbury Academic.

Engelien, K. L., Eriksen, T. M. \& Jakhelln, R. E. (2015). Integrerte studiedesign for fremragende lærerutdanning. I U. E. Rindal, A. Lund \& R. E. Jakhelln (red.), Veier til fremragende loererutdanning (s. 157-169). Oslo: Universitetsforlaget.

Eriksen, T. M. (2016). Fra fortellinger om klasserommet til forskende fellesskap. https://utdanningsforskning.no/artikler/fra-fortellinger-om-klasserommet-til-forskendefellesskap/

Gibbs, G. (2010). Dimensions of Quality. York: The Higher education Academy. https://www.advance-he.ac.uk/knowledge-hub/dimensions-quality

Glenn, W. J. (2006). Model versus mentor: Defining the necessary qualities of the effective cooperating teacher. Teacher Education Quarterly, 33(1), 85-95.

Grimen, H. (2008). Profesjon og kunnskap. I A. Molander \& L. I. Terum (red.), Profesjonsstudier (s. 71-86). Oslo: Universitetsforlaget.

Grossman, P., Compton, C., Igra, D., Ronfeldt, M., Shahan, E. \& Williamson, P. (2009a). Teaching practice: A cross-professional perspective. The Teachers College Record, 111(9), 2055-2100.

Grossman, P., Hammerness, K. \& McDonald, M. (2009b). Redefining teaching, re-imagining teacher education. Teachers and Teaching: theory and practice, 15(2), 273-289.

Grossman, P., Hammerness, K. M., McDonald, M. \& Ronfeldt, M. (2008). Constructing Coherence: Structural Predictors of Perceptions of Coherence in NYC Teacher Education Programs. Journal of Teacher Education, 59(4), 273-287. https://doi.org/10.1177/0022487108322127

Handal, G. (1990). Studiekvalitet. Innstilling fra studiekvalitetsutvalget avgitt til Utdanningsog forskningsdepartementet 9. juli 1990.

Hatlevik, I. K. R. (2016). Hvordan utvikle og kontrollere prosesskvalitet? Uniped, 39(3), 195210.

Hatlevik, I. K. R. (2018). God undervisning og studenter som lykkes. En sammenligning av teoretiske og empiriske bidrag fra tre forskningsretninger. Nordic Studies in Education, 38(3), 271-286. https://doi.org/10.18261/issn.1891-5949-2018-03-06

Hatlevik, I. K. R., Hunskaar, T. S. \& Eriksen, T. M. (2020). Universitet og skole i samarbeid om lærerutdanning - Universitetet i Oslo sin modell for utvidet partnerskap. I. E. Elstad (red.), Laererutdanning $i$ nordiske land (s. 277-295). Oslo: Universitetsforlaget.

Hatlevik, I. K. R. \& Lejonberg, E. (2019). Mentoroppfølging i lektorutdanningen: Hvordan oppfølging ved en mentor kan bidra til en god studiestart for lektorstudenter. Acta Didactica, 13(1), Art. 2. http://dx.doi.org/10.5617/adno.5485

Hatlevik, I. \& Smeby, J.-C. (2015). Programme coherence and epistemological beliefs. Nordic Psychology, 67(2), 136-153. doi: https://doi.org/10.1080/19012276.2015.1031553 
Havnes, A. (2011). Fra høgskole til universitet. Utfordringer knyttet til profesjonsrettet profil. HiO-rapport 2011, nr. 8. Oslo: Høgskolen i Oslo.

Hunskaar, T. S. \& Borge, I. C. (2015). Ønsker du å utvikle matematikkundervisningen din? I U. E. Rindal, A. Lund \& R. E. Jakhelln (red.), Veier til fremragende loererutdanning (s. 99-110). Oslo: Universitetsforlaget.

Hunskaar, T. S. \& Eriksen, T. M. (2019). University Schools as Partners: The Jewel in the Crown of Teacher Education. I K. Kleemann, J. Jennek \& M. Vock (red.), Kooperation von Universität und Schule fördern. Schulen stärken, Lehrerbildung verbessern (s. 257277). Berlin: Verlag Barbara Budrich.

ILS (2011). Fagvisjoner i pedagogisk praksis. En modell for fornying av loererutdanningen. http://www.uv.uio.no/ils/studier/kvalitet/pupils/pupils-rapport.pdf

ILS (2012). Referat fra ekstraordincert møte i programrådet for Lektorprogrammet 14.05.2012. https://www.uv.uio.no/ils/om/organisasjon/programrad/lep/tidligerereferater/referat $140512 . \mathrm{html}$

ILS (2018). Invitasjon til å søke status som universitetsskole ved UiO for perioden 2018 2022. https://www.uv.uio.no/ils/forskning/prosjekter/universitetsskolesamarbeidet/ils utlysning-univeritetsskoler-(002).pdf

Jakhelln, R. E., Lund, A. \& Vestøl, J. M. (2017). Universitetsskoler som arena for nye partnerskap og profesjonskvalifisering. I S. Mausethagen \& J.-C. Smeby (red.), Kvalifisering til profesjonell yrkesutøvelse (s. 70-82). Oslo: Universitetsforlaget.

Jenset, I. S., Hammerness, K. \& Klette, K. (2019). Talk about field placement within campus coursework: Connecting theory and practice in teacher education. Scandinavian Journal of Educational Research, 63(4), 632-650. https://doi.org/10.1080/00313831.2017.1415968

Kennedy, M. (2016). Parsing the Practice of Teaching. Journal of Teacher Education, 67(1), 6-17. https://doi.org/10.1177/0022487115614617

Kunnskapsdepartementet (2005). Forskrift om rammeplan for praktisk-pedagogisk utdanning for yrkesfag for trinn 8-13. https://www.regjeringen.no/globalassets/upload/kd/hoeringsdok/2012/12_3854/forskrift_r ammeplan_praktisk_pedagogisk_utdanning_yrkesfag_trinn_8 13 korrigertversjon05091 2.pdf

Kunnskapsdepartementet (2017). Loererutdanning 2025. Nasjonal strategi for kvalitet og samarbeid i loererutdanningene.

https://www.regjeringen.no/contentassets/d0c1da83bce94e2da21d5f631bbae817/kd nasjo nal-strategi-for-larerutdanningene nett.pdf

Kvernbekk, T. (2001). Om pedagogikkens faglige identitet. I: T. Kvernbekk (red.), Pedagogikk og laererprofesjonalitet (s. 17-30). Oslo: Gyldendal Akademisk.

Lejonberg, E., Elstad, E. \& Hunskaar, T. S. (2017). Behov for å utvikle "det tredje rom" i relasjonen mellom universitet og praksisskoler. UNIPED, 40(1), 68-85. https://doi.org/10.18261/issn.1893-8981-2017-01-06

Lillejord, S. \& Børte, K. (2016). Partnership in teacher education - a research mapping. European Journal of Teacher Education 39(5), 550-563. https://doi.org/10.1080/02619768.2016.1252911

Lillejord, S. \& Børte, K. (2014). Partnerskap i laererutdanningen. En forskningskartlegging. KSU 3/2014.

https://www.forskningsradet.no/siteassets/publikasjoner/1254004170214.pdf

Lund, A. \& Eriksen, T. M. (2016). Teacher Education as Transformation: Some Lessons

Learned from a Centre for Excellence in Education. Acta Didactica Norge, 10(2), 53-72. 
Norgesnettrådet (1999). «Basert på det fremste...?» Om evaluering, kvalitetssikring og kvalitetsutvikling av norsk høgre utdanning. Vurderinger og tilrådinger fra arbeidsgruppe nedsatt av Norgesnettrådet. Norgesnettrådets rapporter, 2/1999. Oslo: Norgesnettrådet.

Ottersen, O. P. (2011). Lansering av prosjekt Universitetsskole. UiO, Rektors blogg 17. april 2011.

Pascarella, E. T. \& Terenzini, P. T. (2005). How College Affects Students. Volume 2. A Third Decade of Research. San Francisco: Jossey-Bass.

Pintrich, P. R. (2003). A motivational science perspective on the role of student motivation in learning and teaching contexts. Journal of Educational Psychology, 95(4), 667-686.

Ramsden, P. (2003). Learning to teach in higher education (2. utg.). London: RoutledgeFalmer.

Smeby, J.-C. (2008). Profesjon og utdanning. I A. Molander \& L. I. Terum (red.), Profesjonsstudier (s. 87-102). Oslo: Universitetsforlaget.

Smeby, J.-C. \& Heggen, K. (2014). Coherence and the development of professional knowledge and skills. Journal of Education \& Work, 27(1), 71-91. https://doi.org/10.1080/13639080.2012.718749

Stensaker, B. (2013). Politikk, praksis og nyere perspektiver: Kvalitet i nordisk høyere utdanning. I Y. Nordkvelle, T. Fossland \& G. Netteland (red.), Kvalitet i fleksibel høyere utdanning - nordiske perspektiver (s. 41-52). Trondheim: Akademika.

Stølen, S. \& Mo, G. B. (2018). Gratulerer til våre 18 nye universitetsskoler! UiO, Rektorbloggen 10. august 2018.

https://www.uio.no/om/aktuelt/rektorbloggen/2018/universitetsskoler.html

Sullivan, W. M. (2005). Work and Integrity. The Crisis and Promise of Professionalism in America (2. utg.). San Francisco: Jossey-Bass.

$\mathrm{UiO}$ (2009). Forslag til strukturelle og organisatoriske endringer av Lektorprogrammet ved UiO. Innstilling fra Revisjonskomiteen for Lektor-og adjunktprogrammet. https://docplayer.me/19098068-Forslag-til-strukturelle-og-organisatoriske-endringer-avlektorprogrammet-ved-uio-innstilling-fra-revisjonskomiteen-for-lektor-ogadjunktprogrammet.html

Uniforum (2011). UiO utpeker 13 universitetsskoler. [Solbrekke sitat] https://www.uniforum.uio.no/nyheter/2011/12/uio-utpeker-13-universitetsskoler.html

Vestøl, J. M. (2015). Hva er kvalitet i lærerutdanningen? I U. E. Rindal, A. Lund \& R. E. Jakhelln (red.), Veier til fremragende laererutdanning (s. 202-210). Oslo: Universitetsforlaget.

Vestøl, J. M., Lund, A. \& Jakhelln, R. E. (2015). Design av lærerutdanning. I U. E. Rindal, A. Lund \& R. E. Jakhelln (red.), Veier til fremragende loererutdanning (s. 211-220). Oslo: Universitetsforlaget.

Wittek, L. \& Kvernbekk, T. (2011). On Problems of Asking for a Definition of Quality in Education. Scandinavian Journal of Educational Research, 55(6), 671-684.

Zeichner, K. (2002). Beyond traditional structures of student teaching. Teacher Education Quarterly, 29(2), 59-64.

Zeichner, K. (2010). Rethinking the connections between campus courses and field experiences in college- and university-based teacher education programs. Journal of Teacher Education, 89(11), 89-99.

Aamodt, P. O., Hovdhaugen, E. \& Prøitz, T. S. (2014). Utdanningskvalitet i høyere utdanning: Noen empiriske eksempler. Resultater fra en undersøkelse blant faglig ansatte våren 2013. NIFU-rapport 6-2014. Oslo: NIFU. 


\section{Vedlegg}

Tabell 2. Oversikt over datakilder etter eksempler fra universitetsskolesamarbeidet som presenteres og analyseres.

\begin{tabular}{|c|c|}
\hline Eksempler & Datakilder \\
\hline $\begin{array}{l}\text { Intensjons- } \\
\text { avtalen }\end{array}$ & 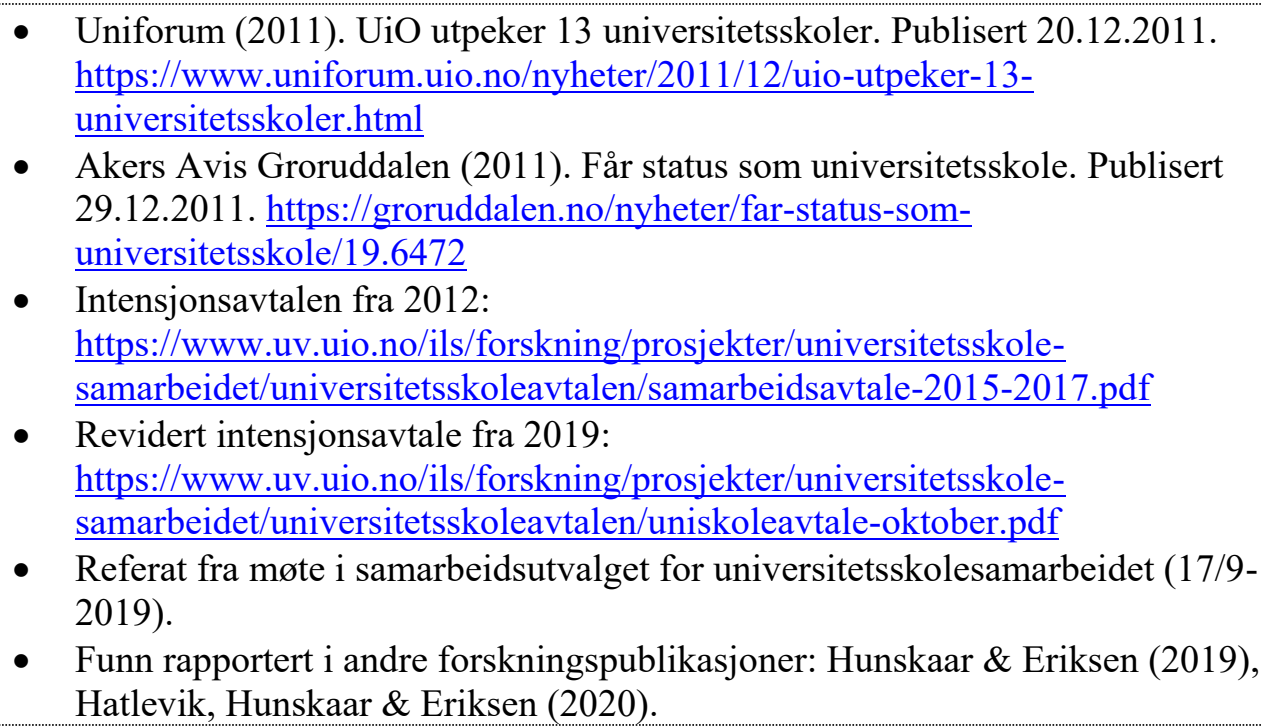 \\
\hline $\begin{array}{l}\text { Styring og } \\
\text { ledelse av } \\
\text { lærer- } \\
\text { utdanningen }\end{array}$ & $\begin{array}{l}\text { - Protokoller for Fakultetsstyret ved UV-fakultetet ved UiO: } \\
\text { https:/www.uv.uio.no/om/organisasjon/styret/ } \\
\text { - } \begin{array}{l}\text { Protokoller fra Instituttstyret ved ILS: } \\
\text { https://www.uv.uio.no/ils/om/organisasjon/styret/ }\end{array} \\
\text { - } \begin{array}{l}\text { Protokoller fra Program- og fagråd ved ILS: } \\
\text { https://www.uv.uio.no/ils/om/organisasjon/programrad/ }\end{array}\end{array}$ \\
\hline $\begin{array}{l}\text { Lektor- } \\
\text { programmet }\end{array}$ & 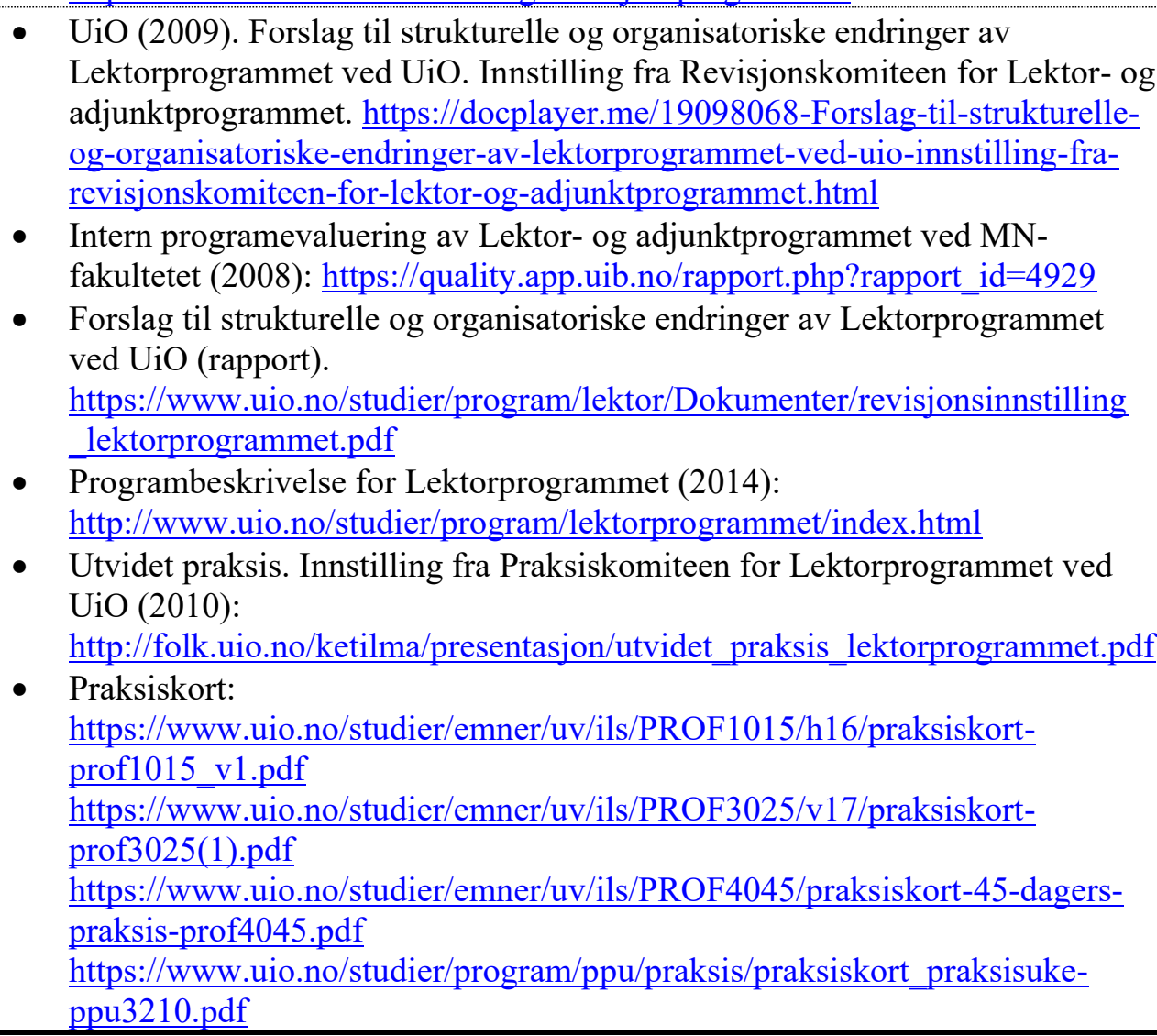 \\
\hline
\end{tabular}




\begin{tabular}{|c|c|}
\hline & $\begin{array}{l}\text { https://www.uio.no/studier/program/ppu/praksis/praksiskort 3- } \\
\text { ukerspraksis_ppu3210.pdf } \\
\text { https://www.uio.no/studier/program/ppu/praksis/praksiskort-8-ukers- } \\
\text { praksis 2.pdf }\end{array}$ \\
\hline $\begin{array}{l}\text { Integrert } \\
\text { profesjonsfag } \\
\text { for PPU og } \\
\text { Lektor- } \\
\text { programmet }\end{array}$ & 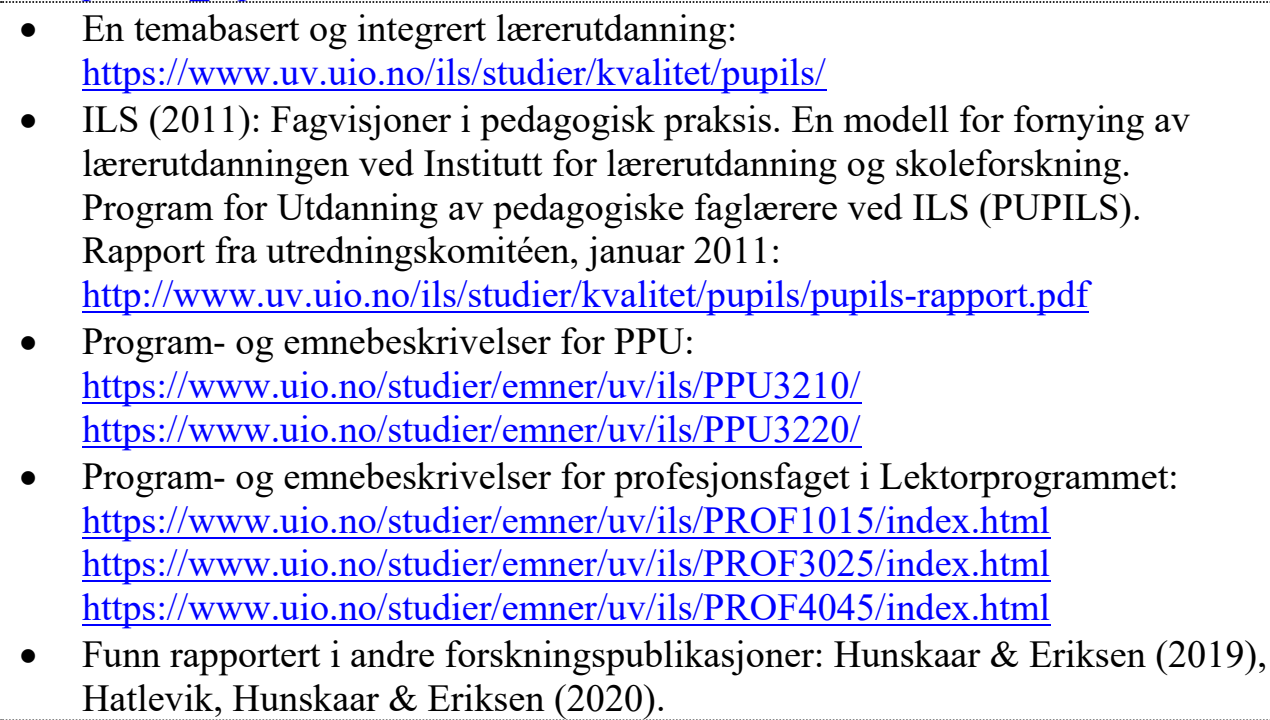 \\
\hline $\begin{array}{l}\text { Profesjonsrettet } \\
\text { mentorordning } \\
\text { for } \\
\text { lektorstudenter }\end{array}$ & $\begin{array}{l}\text { - Emnebeskrivelser for PROMO 1-10: } \\
\text { https://www.uio.no/studier/program/lektorprogrammet/promo/ } \\
\text { - Funn rapportert i annen forskningspublikasjon: Hatlevik \& Lejonberg } \\
\text { (2019). }\end{array}$ \\
\hline
\end{tabular}

